\title{
ON SOME GENERALIZATIONS OF OSTROWSKI INEQUALITY FOR LIPSCHITZ FUNCTIONS AND FUNCTIONS OF BOUNDED VARIATION
}

\author{
LJ. Dedić, M. MATIĆ AND J. PEČARIĆ
}

Abstract. Some generalizations of Ostrowski inequality for Lipschitz functions and functions of bounded variation are given.

Mathematics subject classification (1991): 26D10, $26 \mathrm{D} 15$.

Key words and phrases: Ostrowski inequality, Lipschitz functions, bounded variation.

\section{REFERENCES}

[1] A. OsTROWSKI, Uber die Absolutabweichung einer differentierbaren Funktionen von ihren Integralmittelwort, Comment. Math. Helv., 10 (1938), 226-227.

[2] D. S. MitRINOVIĆ, J. PEČARIĆ AND A. M. FINK, Inequalities involving functions and their integrals and derivatives, Kluwer Acad.Publ., Dordrecht, 1991.

[3] G. V. MilOVANOVIĆ AND J.E. PEČARIĆ, On generalizations of the inequality of A. Ostrowski and some related applications, Univ. Beograd. Publ. Elektrotehn. Fak., Ser. Mat. Fiz., No 544-No 576 (1976), $155-158$.

[4] A. M. FINK, Bounds on the deviation of a function from its averages, Czechoslovak Math. J., 42(117) (1992), 289-310.

[5] S. S. DRAGomir AND S. WANG, A new inequality of Ostrowski's type in $L_{1}$-norm and applications to some special means and to some numerical quadrature rules, Thamkang J. Math., 28, 2 (1997), 239-244.

[6] S. S. DRAGOMIR AND S. WANG, A new inequality of Ostrowski's type in $L_{p}$-norm and applications to some special means and to some numerical quadrature rules, Thamkang J. Math., to appear.

[7] S. S. DRAGOMIR, On the Ostrowski inequality for mappings with bounded variation and applications, RGMIA, 2, No. 1, 1999.

[8] J. E. PEČARIĆ AND B. SAVIĆ, O novom postupku razvijanja funkcija u red i nekim primjenama, Zbornik radova VA KoV (Beograd) 9 (1983), 171-202.

[9] S. S. Dragomir, P. CERONE, J. Roumeliotis AND S. WANG, A weighted version of Ostrowski inequality for mappings of Hölder type and applications in numerical analysis, RGMIA, 2, No. 1, 1999.

[10] LJ. DEDIĆ, J. PEČARIĆ AND N. UJEVIĆ, On generalizations of Ostrowski inequality and some related results, submitted.

[11] M. MATIĆ, J. PEČARIĆ AND N. UjeVIĆ, On new estimation of the remainder in generalized Taylor's formula, Math. Inequal. Appl. 2 (1999), 343-361. 